Utah State University

DigitalCommons@USU

$1-1-1977$

\title{
Measurement of the Nitric Oxide Altitude Distribution in the Mid- Latitude Mesosphere
}

K. D. Baker

A. F. Nagy

R. O. Olsen

E. S. Oran

J. Randhawa

D. F. Strobel

Utah State University

See next page for additional authors

Follow this and additional works at: https://digitalcommons.usu.edu/sdl_pubs

\section{Recommended Citation}

Baker, K. D.; Nagy, A. F.; Olsen, R. O.; Oran, E. S.; Randhawa, J.; Strobel, D. F.; and Tohmatsu, T., "Measurement of the Nitric Oxide Altitude Distribution in the Mid-Latitude Mesosphere" (1977). Space Dynamics Lab Publications. Paper 7.

https://digitalcommons.usu.edu/sdl_pubs/7

This Article is brought to you for free and open access by the Space Dynamics Lab at DigitalCommons@USU. It has been accepted for inclusion in Space Dynamics Lab Publications by an authorized administrator of DigitalCommons@USU. For more information, please contact digitalcommons@usu.edu.

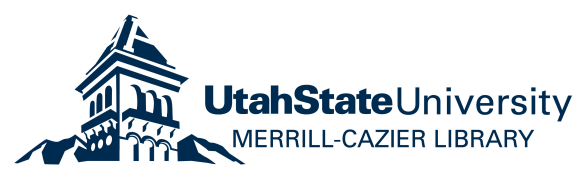


Authors

K. D. Baker, A. F. Nagy, R. O. Olsen, E. S. Oran, J. Randhawa, D. F. Strobel, and T. Tohmatsu

This article is available at DigitalCommons@USU: https://digitalcommons.usu.edu/sdl_pubs/7 
Baker, K. D., A. F. Nagy, R. O. Olsen, E. S. Oran, J. Randhawa, D. F. Strobel, and T. Tohmatsu. 1977. "Measurement of the Nitric Oxide Altitude Distribution in the Mid-latitude Mesosphere." Journal of Geophysical Research 82 (22): 3281-86. doi:10.1029/JA082i022p03281.

VOL. 82 , NO. 22

JOURNAL OF GEOPHYSICAL RESEARCH

AUGUST 1, 1977

\title{
MEASUREMENT OF THE NITRIC OXIDE ALTITUDE DISTRIBUTION IN THE MID-LATITUDE MESOSPHERE
}

\author{
K. D. Baker ${ }^{1}$, A. F. Nagy ${ }^{1,2}$, R. O. $01 \operatorname{sen}^{3}$, E. S. Oran ${ }^{4}$,
} J. Randhawa ${ }^{3}$, D. F. Strobe $1^{4}$, and T. Tohmatsu ${ }^{5}$

Abstract. A simple rocket-borne system has been developed for deriving nitric oxide concentration in the mesosphere from measurements of resonantly scattered solar ultraviolet radiation in the NO gamma band near $2150 \AA$. The No signal is extracted from a background of Rayleigh-scattered light by a direct measurement of this scattered light by use of an NO absorption cell. This system was utilized to measure the NO concentration above White Sands, New Mexico, in the altitude range from 69 to 101 $\mathrm{km}$. The derived NO profile shows a concentration of about $3 \times 10^{7} \mathrm{~cm}^{-3}$ at 67 and $100 \mathrm{~km}$ with a deep valley (more than an order of magnitude less) at about $84 \mathrm{~km}$. Comparison with model calculations indicates that the time constant for NO chemistry is smaller than or comparable with that for transport.

\section{Introduction}

Satellite and rocket measurements of nitric oxide gamma band fluorescence can be used to deduce nitric oxide concentrations in the thermosphere and mesosphere [Barth, 1964, 1966a, b]. In the mesosphere the measurement is complicated by a background signal due to Rayleigh scattering of solar radiation by atmospheric molecules. The satellite-borne spectrometers provide meaningful data only about $90 \mathrm{~km}$, where Rayleigh scattering is smal1 [Rusch, 1973; Barth et a1., 1973; Rusch and Barth, 1975].

A number of vertical No density profiles in the 70 - to $110-\mathrm{km}$ region have been inferred from rocket-borne spectrometer measurements of $\gamma$ $(1,0)$ band fluorescence [e.g., Barth, 1966a, b; Pearce, 1969; Meira, 1971; Tisone, 1973]. In the mesosphere the subtraction of a large Rayleigh scattering component from the measured signal is necessary to recover the small $\gamma(1,0)$ band column emission rate. Since the Rayleigh scattering component is normally deduced from atmospheric density measurements, the resultant $\gamma(1,0)$ band column emission has large uncertainties associated with it. To deduce the volume emlssion rate and hence the local No density, differentiation of the noisy column emission is required; and therefore the error bars are large

\footnotetext{
${ }^{1}$ Center for Research in Aeronomy, Utah State University, Logan, Utah 84322.

${ }^{2}$ Department of Atmospheric and Oceanic Sciences, University of Michigan, Ann Arbor, Michigan 48109. ${ }^{3}$ Atmospheric Science Laboratory, White Sands Missile Range, New Mexico 88002.

${ }^{4}$ Naval Research Laboratory, Washington, D. C. 20375.

5 Geophysics Research Laboratory, University of Tokyo, Tokyo 113, Japan.
}

Copyright 1977 by the American Geophysical Union. on the derived NO concentrations below the mesopause.

A sma11 and uncomplicated photometer system has been developed for rocket-borne NO measurements which allows us, in principle, to obtain accurately both the $\gamma(1,0)$ band emission and the background Rayleigh-scattered component [Tohmatsu and Iwagami, 1975]. The purpose of this brief note is to describe this photometer system and to present a rocket measurement of the NO concentration about White Sands, New Mexico, on October 4, 1973. The measurement is compared with previous fluorescence measurements of NO with theoretical calculations.

\section{Instrument Description}

The rocket experiment uses an ultraviolet photometer coupled with a nitric oxide gas-filled optical absorption cell to remove correctly the Rayleigh-scattered background signal and to measure accurately the small $\gamma(1,0)$ band emission in the mesosphere. The block diagram (Figure 1) illustrates the basic principle of operation of the photometer system. An 18- cm solar baffle $6.4 \mathrm{~cm}$ in diameter and a honeycomb collimator with a circular field of view of $6^{\circ}$ precede an interference filter. The center wavelength of this prefilter is $2160 \&$ with a half-power transmission width of $80 \AA$. Two optical cells are alternately placed into the optical path between the prefilter and the photomultiplier tube (Hammamatsu R431S). The optical cells are $3 \mathrm{~cm}$ in diameter, have a $2-\mathrm{cm}$ path length, and are made of optical silica. The first cell is unfilled, while the second is filled with pure No at a pressure of 200 torrs. These cells are cycled back and forth at a frequency of $1 \mathrm{~Hz}$. The NO cell acts as a rejection filter for NO gamma band emissions terminating at the ground vibrational leve1 $\left(v^{\prime \prime}=0\right)$. Figure 2 reproduces the results of a laboratory test showing clearly the removal of the $(0,0),(1,0)$, and $(2,0)$ bands by the NO cell, while the other features $\left(v^{\prime \prime} \neq 0\right)$ remain unchanged. Thus the difference in the output signal with the different cells in the optical path corresponds to the intensity of the $(1,0)$ gamma band of No at $2148 \AA$. A discussion of the calibration and data analysis details are given by Tsang [1975] and Tohmatsu and Iwagami [1976].

\section{Results}

The No photometer system described above was flown aboard a Nike-Apache rocket launched from the White Sands Proving Grounds at $1854 \mathrm{MDT}$ on October 4, 1973. The solar zenith angle was $92.15^{\circ}$ at launch and $92.7^{\circ}$ at the time of rocket apogee. The nose tip cover was ejected at an altitude of $69 \mathrm{~km}$, and the rocket reached an apogee of $101 \mathrm{~km}$; useful data were obtained only during the upleg portion of the flight. The photometer sampling rate was 18 samples/s, and the zenith 


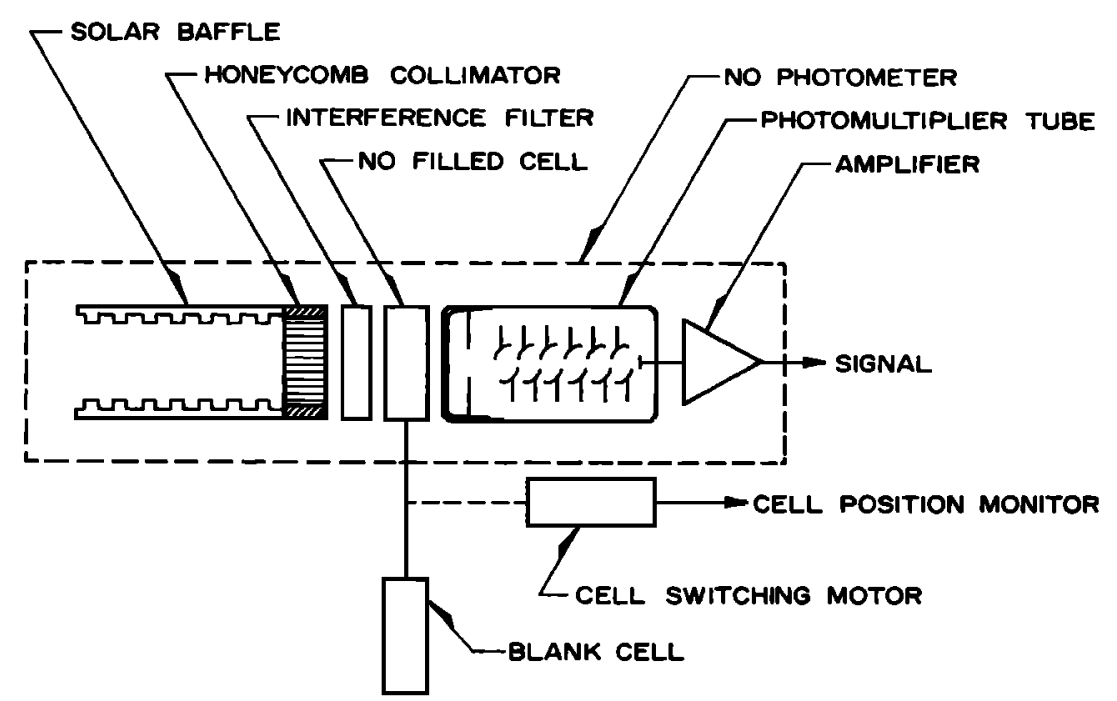

Fig. 1. Schematic of photometer system for measurement of nitric oxide gamma band fluores cence.

intensities (raw data points corrected for rocket aspect) thus obtained are shown in Figure 3. These data points were averaged over the period of cell dwe1l position ( $0.5 \mathrm{~s})$ and the signal with the No cell in position subtracted from the signal with the blank cell in position. The resulting $(1,0)$ gamma band zenith emission data are shown in Figure 4. A polynomial least squares fit to these data points and plus or minus one standard deviation flags is also shown in Figure 4. The resulting polynomial expression was differentiated to yield the volume emission rate and then converted to the NO densities shown in Figure 5 with an emission rate factor $g$ of $7.68 \times 10^{-6}$ [Cravens, 1977]. A check for the possible extinction of solar radiation at $2150 \AA$ by ozone (ozone densities were taken from the U.S. Standard Atmosphere (1976) and the absorption cross section

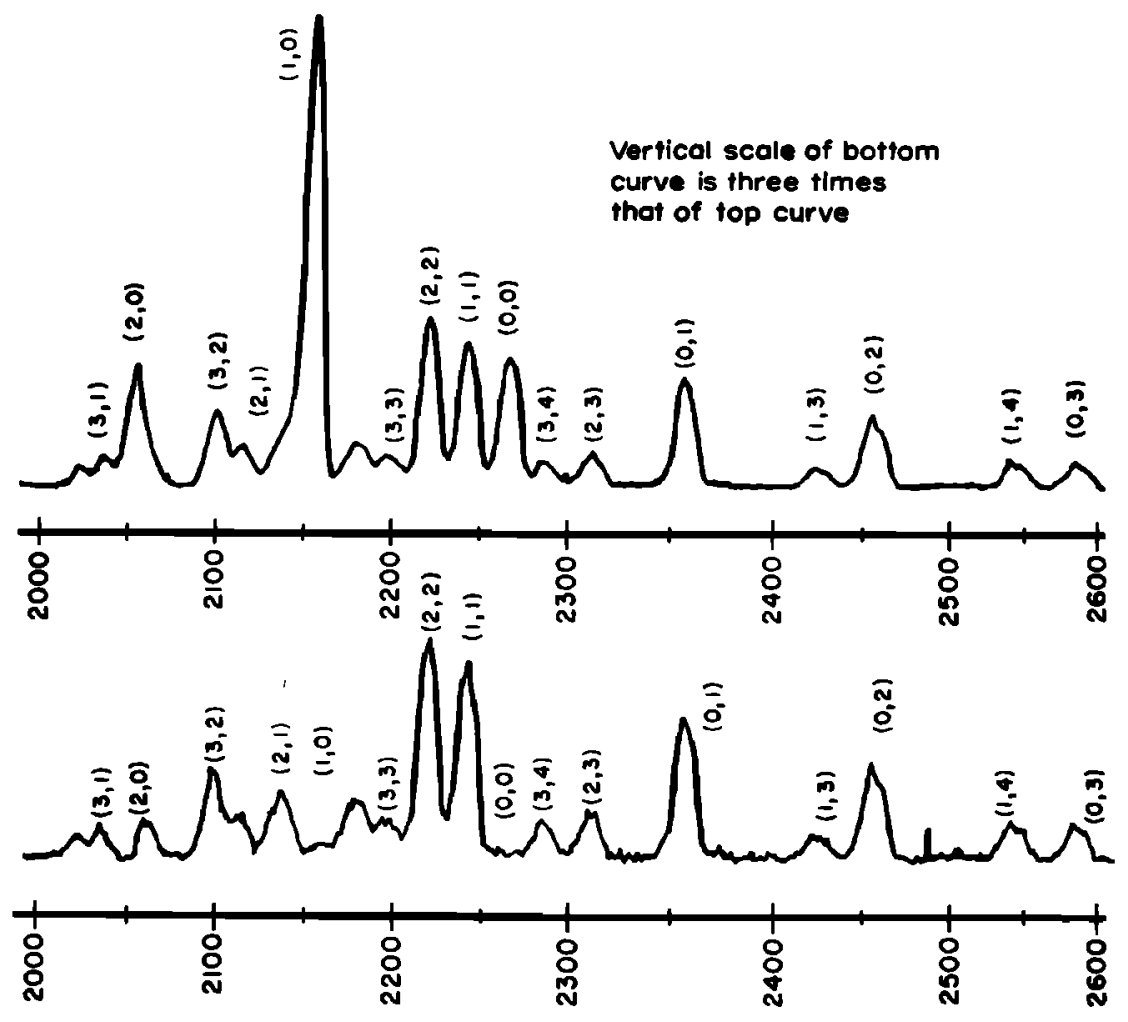

WAVELENGTH (A)

Fig. 2. Laboratory spectra of No gamma band fluorescence. (Top) Spectrum taken with blank ce1l. (Bottom) Spectrum taken with No absorption cell. Note that the $v^{\prime \prime}=0$ progression bands are completely removed in the lower spectrum. 
from Hudson and Kieffer [1975] indicated that the ozone optical depth $\tau_{0_{3}}(2150 \AA)$ was less than 0.1 , even as low as $70 \mathrm{~km}$. It was also established that the sunward column density of No was less than $1.5 \times 10^{15}$, which according to the work of Cravens [1977] would reduce the emission rate factor by less than $10 \%$. Considering the present uncertainties $(\sim 10 \%)$ in this rate, it was considered inappropriate to attempt to introduce any corrections. Figure 5 also shows, for the sake of comparison, other inferred mid-latitude NO density profiles (normalized by using the presently accepted value of the $g$ factor).

\section{Model Calculations and Discussion}

One complication in modeling the experimental results is that October 3, 1973, was a geomagnetically disturbed day. Analysis of Atmosphere Explorer ( $\mathrm{AE}$ ) data has shown that geomagnetic storms produce large-scale horizontal gravity waves that propagate away from the auroral zones as well as a meridional circulation that transports No-rich air from the auroral regions to mid-latitudes [Cravens and Stewart, 1976]. As the temperature perturbations propagate through the atmosphere, they locally enhance the reaction rates of $\mathrm{N}\left({ }^{4} \mathrm{~S}\right)+\mathrm{O}_{2} \rightarrow \mathrm{NO}+\mathrm{O}$ and cause sub-

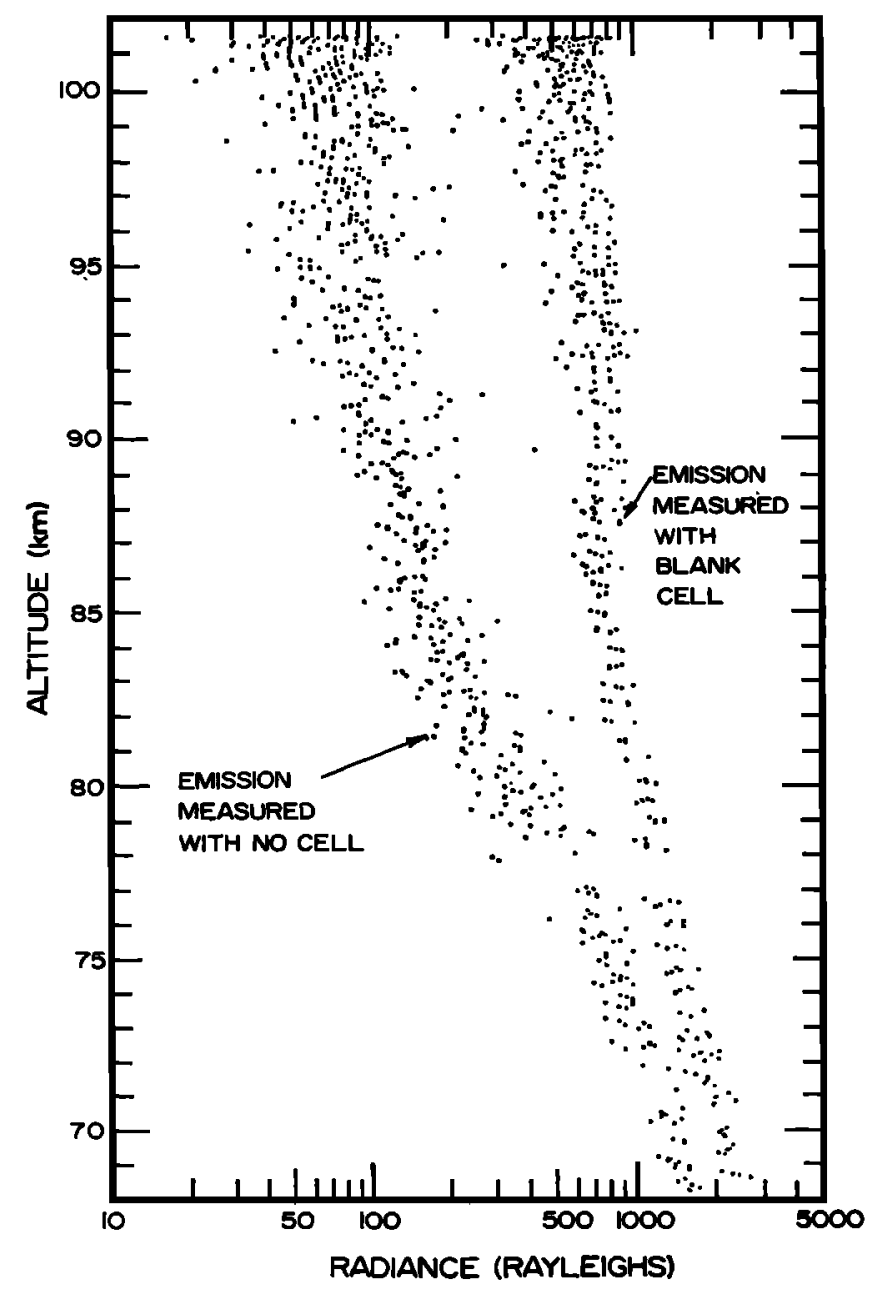

Fig. 3. Raw data points of zenith intensities observed with the NO cell and the blank cell.

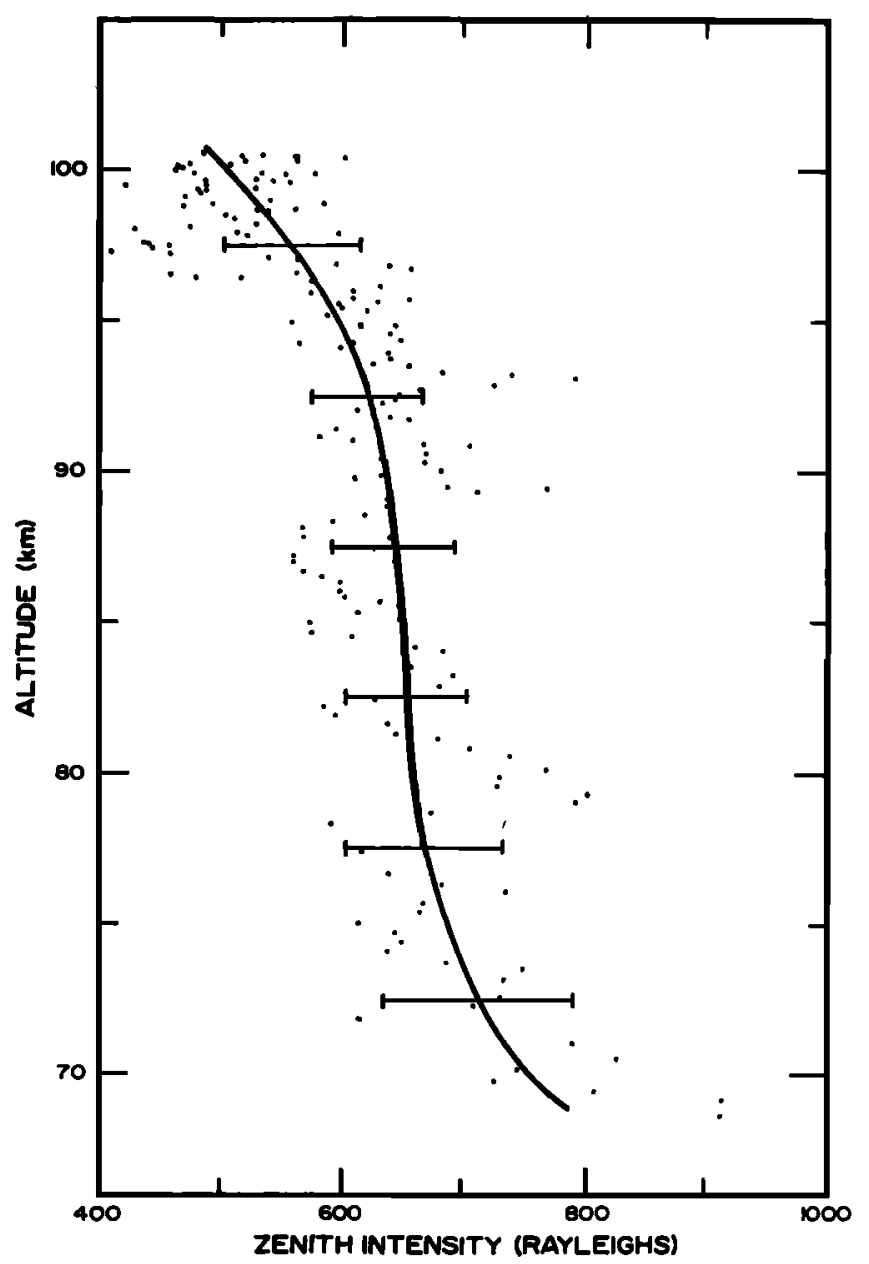

Fig. 4. The zenith emission of the NO $(1,0)$ gamma band measured with rocket-borne photometer.

stantial amounts of $\mathrm{N}\left({ }^{4} \mathrm{~S}\right)$ to be converted to NO. To include all these physical processes in a model is beyond the scope of this brief report. Instead, we used the Naval Research Laboratory model of atmospheric odd nitrogen which is part of a one-dimensional model of the mid-1atitude ionosphere [Oran et a1., 1975; Strobel et a1., 1976]. The primary region of interest is below $95 \mathrm{~km}$, where the production rate of odd nitrogen is exceedingly small. The major No source is a downward flux from the thermosphere that can be simulated if the observed No concentration at $100 \mathrm{~km}$ can be approximately calculated. Such a procedure has been successfully employed by Strobel [1971, 1972]. One uncertain parameter in odd nitrogen models is the reaction rate of $N\left({ }^{2} \mathrm{D}\right)+0 \rightarrow N\left({ }^{4} S\right)+0$. Davenport et al. [1976] have measured a rate of $1.7 \times 10^{-12} \mathrm{~cm}^{3} \mathrm{~s}^{-1}$ at $300^{\circ} \mathrm{K}$ in the laboratory, whereas Frederick and Rusch [1977] have inferred $4 \times 10^{-13 \mathrm{~cm}^{3} \mathrm{~s}^{-1} \text { at }}$ thermospheric temperatures from Atmosphere Explorer data analysis. To obtain the observed No concentration at $100 \mathrm{~km}$, we used the reaction rate inferred by Frederick and Rusch [1977].

In Figure 6 the results of our model calculations are shown for three choices of eddy diffusion coefficient profiles: (1) $\mathrm{K}=4.5 \times 10^{6}$, (2) $\mathrm{K}=1 \times 10^{6}$, and (3) $\mathrm{K}=1 \times 10^{6} \exp$ $[(z-100 \mathrm{~km}) / 2 \mathrm{H}] \mathrm{cm}^{2} \mathrm{~s}^{-1}$. Case 3 obviously gives the best fit to the observational data. 


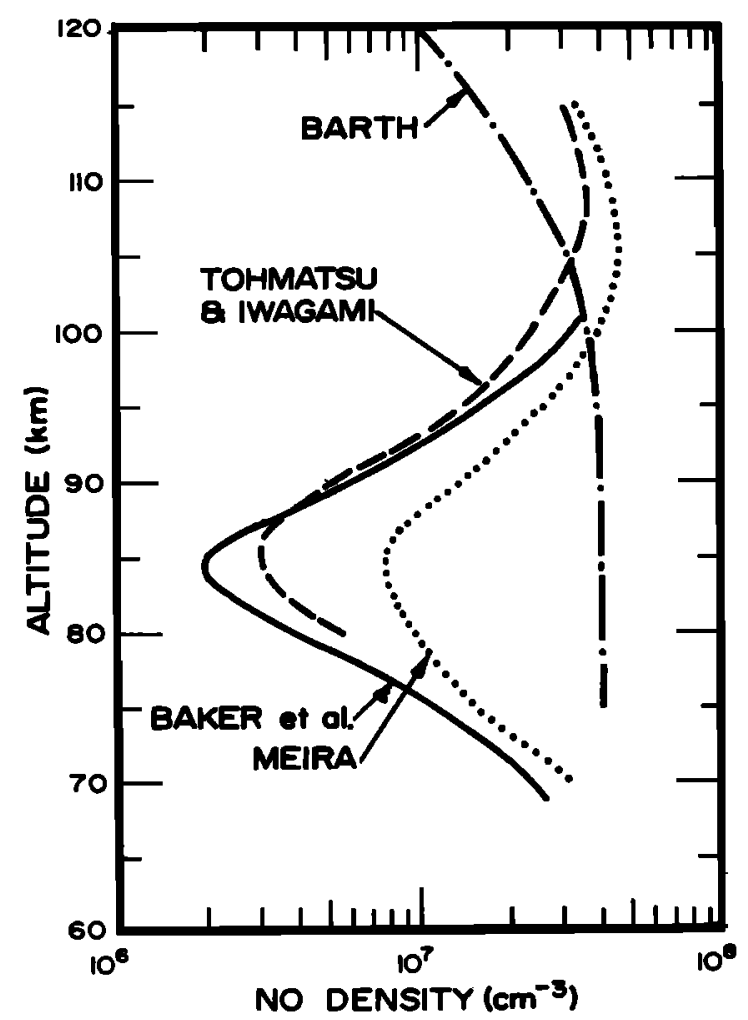

Fig. 5. Nitric oxide density profile deduced from the data of Figure 4 compared with profiles of other workers [Barth, 1966b; Meira, 1971; Tohmatsu and Iwagami, 1975].

To understand the basic chemistry and physics that determine the No density profile below $100 \mathrm{~km}$, 1t is instructive to consider analytic solutions to the relevant NO flux and continuity equations

$$
\begin{gathered}
\phi=-\mathrm{K}\left[\frac{\mathrm{dn}}{\mathrm{dz}}+\left(\frac{1}{\mathrm{~T}} \frac{\mathrm{dT}}{\mathrm{dz}}+\frac{1}{\mathrm{H}}\right) \mathrm{n}\right] \\
\mathrm{d} \phi / \mathrm{dz}=-\mathrm{J} *_{\mathrm{n}}
\end{gathered}
$$

respectively, where $H$ is the scale height of the background atmosphere, $\mathrm{J}^{*}$ is twice the diurnally averaged predissociation rate of No and reflects the fact that the $\mathrm{N}$ atom produced in dissociation reacts and removes another No molecule, and the other symbols have their customary meanings. If we assume that $\mathrm{J}^{*}, \mathrm{~K}$, and $\mathrm{T}$ have constant values throughout this region, then we obtain

$$
n=c_{1} \exp \left[p_{+}(z-95)\right]+c_{2} \exp \left[p_{-}(z-95)\right]
$$

where

$$
\mathrm{p}_{ \pm}=-\frac{1}{2 \mathrm{H}}\left[1+(1+\mathrm{r})^{\frac{1}{2}}\right] \quad \mathrm{r}=4 \mathrm{H}^{2} \mathrm{~J}^{*} / \mathrm{K}>0
$$

and $z$ is in kilometers. The appropriate boundary conditions are $\mathrm{n} \simeq 1.3 \times 10^{7} \mathrm{~cm}^{-3}$ at $95 \mathrm{~km}$ (cf. Figure 6) and $\phi \simeq 0$ at $70 \mathrm{~km}$ as discussed in Oran et a1. [1975]. (Note that the numerical accuracy of the computer solution for $n$ is not sufficient to enforce $\phi=0$ at $70 \mathrm{~km}$. In practice, the solution satisfies $|\phi|<10^{7} \mathrm{~cm}^{-2} \mathrm{~s}^{-1}$ at $70 \mathrm{~km}$.)
For case 1 with $\mathrm{H}=5.8 \mathrm{~km}, \mathrm{~J}^{*}=3.8 \times 10^{-6} \mathrm{~s}^{-1}$, and $K=4.5 \times 10^{6} \mathrm{~cm}^{2} \mathrm{~s}^{-1}$ we find $\mathrm{r} \simeq 2$ and the asymptotic $(r \rightarrow 0)$ solution approximates

$$
\begin{aligned}
& p_{+} \simeq 0 \\
& p_{-} \simeq-1 / H
\end{aligned}
$$

Here the $p_{+}$term represents the maximum diffusion velocity solution, while the $p_{\text {- term represents a }}$ mixed distribution and zero velocity, as was previously discussed by Strobel [1971]. For the 70to $100-\mathrm{km}$ region the $\mathrm{p}_{+}$term is appropriate and the NO density is essentially constant throughout this region, since diffusion occurs more rapidly than chemistry.

For case 2 we find

$$
\begin{aligned}
r & \simeq 10 \\
P_{+} & \simeq 0.2 \mathrm{~km}^{-1} \\
P_{-} & \simeq-0.4 \mathrm{~km}^{-1}
\end{aligned}
$$

Hence we expect in the 85- to $95-\mathrm{km}$ region that the No density will decrease with decreasing altitude as exp $[0.2(\mathrm{z}-95 \mathrm{~km})]$, whereas below $85 \mathrm{~km}$ we anticipate a rapid increase in the No density with decreasing altitude as $\exp [-0.4(\mathrm{z}-$ $95 \mathrm{~km})]$. From the definition of $r$ we deduce that $r \cong 10$ implies comparable time constants for diffusion and dissociation. Case 2 corresponds to the downward NO flux from the thermosphere being

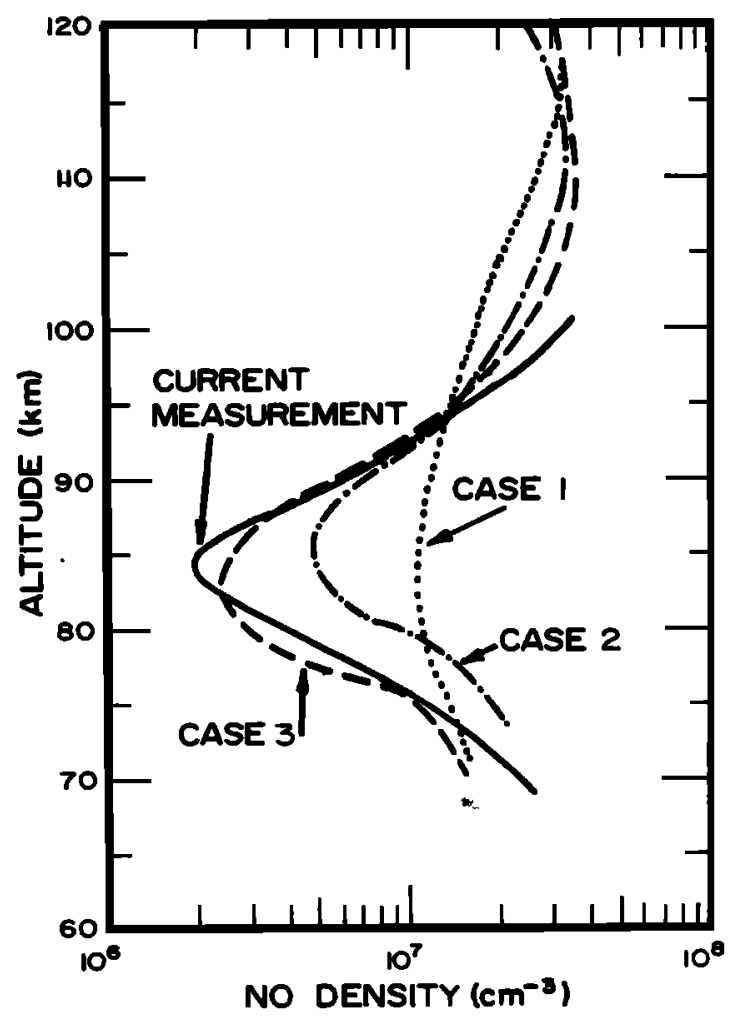

Fig. 6. Comparison of currently reported rocket measurement of No density with three model calculations using different eddy diffusion coefficients: case $1,4.3 \times 10^{6}$; case $2,1 \times 10^{6}$; and case $3,1 \times 10^{6} \exp [(\mathrm{z}-100 \mathrm{~km}) / 2 \mathrm{H}] \mathrm{cm}^{2} \mathrm{~s}^{-1}$. 
chemically depleted by predissociation in the $\delta$ bands and the subsequent reaction of the product $\mathrm{N}$ atoms to form $\mathrm{N}_{2}$. When most of the No molecules have been chemically removed (by approximately $85 \mathrm{~km})$, the No density profile assumes a quasimixed distribution with the departures due to predissociation. In addition, there is a sma1l upward flux of No molecules from the upper stratosphere to this chemical sink in the upper mesosphere [McConne11 and McE1roy, 1973; Brasseur and Nicolet, 1973]. The magnitude of this flux is sufficiently small to maintain a quasi-mixed density profile.

Case $3(r \simeq 40-60)$ represents the opposite extreme where $r \rightarrow \infty$ and

$$
\begin{aligned}
& P_{+} \simeq+(J / K)^{1 / 2} \\
& P_{-} \simeq-(J / K)^{1 / 2}
\end{aligned}
$$

Here chemistry is more rapid than diffusion, and a very deep minimum in the NO concentration profile can be formed with characteristic density height scales of $(\mathrm{K} / \mathrm{J})^{\frac{1}{2}}$ above and below the minimum.

The vertical No density profiles that have been inferred from No fluorescence in $\gamma(1,0)$ and that are shown in Figure 5 suggest that the value of $r$ is in excess of about 10 . This would imply that the time constant for NO chemistry is comparable to or smaller than the transport time constant. It should be realized that large error bars are associated with local No densities and that the conclusions are not definitive. An alternate interpretation is that the structure in the No profile is due to large variations in the eddy diffusion coefficient [Donahue, 1972; Rusch, 1973]. However, the eddy diffusion coefficient in all odd nitrogen models is used as a lumpedtransport parameter representing all scales of motion, and it is highly unlikely that its magnitude changes by an order of magnitude in $s$ scale height.

Summary

The results presented here indicate that a simple and inexpensive photometer system can be used to determine the altitude distribution of nitric oxide in the mesosphere. The inferred No density profile is in reasonably good agreement with the earlier results obtained by Meira [1971] and Tohmatsu and Iwagami [1975]. Since our $\gamma$ $(1,0)$ band fluorescence measurements were made the day after a geomagnetic storm, the observed NO concentrations could not be predicted with a one-dimensional model of the thermosphere. However, we were able to describe the essential chemistry and physics that control the vertical NO density profile in the $70-$ to $100-\mathrm{km}$ region in terms of an analytic solution and the nondimensional parameter $r=4 \mathrm{H}^{2} \mathrm{~J} * / \mathrm{K}$. The experimental results presented here, as well as those of Meira [1971] and Tohmatsu and Iwagami [1975], are consistent with $r \geq 10$. We infer from this that the NO time constant for chemistry is smaller than or comparable to the transport time constant in the mesosphere.
Acknowledgments. The measurements program was sponsored by the Atmospheric Science Laboratory of the U.S. Army Electronics Command. The work of A. F. Nagy was supported by NASA grant NGR23-005-015, while the contributions of D. F. Strobel and E. S. Oran were sponsored by the office of Naval Research.

\section{References}

Barth, C. A., Rocket measurement of the nitric oxide dayglow, J. Geophys. Res., 69, 3301, 1964.

Barth, C. A., Nitric oxide in the upper atmosphere, Ann. Geophys., 22, 198, 1966a.

Barth, C. A., Rocket measurement of nitric oxide in the upper atmosphere, P1anet. Space Sci., 14, $623,1966 \mathrm{~b}$.

Barth, C. A., D. W. Rusch, and A. I. Stewart, The UV nitric oxide experiment on Atmosphere Explorer, Radio Sci., 8, 379, 1973.

Brasseur, G., and M. Nicolet, Chemospheric processes of nitric oxide in the mesosphere and stratosphere, Planet. Space Sc1., 21, 939, 1973.

Cravens, T. E., Nitric oxide gamma band emission rate factor, Planet. Space Sci., in press, 1977.

Cravens, T. E., and A. I. Stewart, The global morphology of nitric oxide (abstract), EOS Trans. AGU, 57, 295, 1976.

Davenport, J. E., T. G. Slanger, and G. Black, The quenching of $N\left({ }^{2} \mathrm{D}\right)$ by $\mathrm{O}\left({ }^{3} \mathrm{P}\right), \mathrm{J}$. Geophys. Res., 81, 12, 1976.

Donahue, T. M., Positive ion chemistry of the $D$ and $E$ regions, Radio Sci., 7, 73, 1972.

Frederick, J., and D. W. Rusch, On the chemistry of metastable atomic nitrogen in the $F$ region deduced from simultaneous satellite measurements of the 5200- $\AA$ airglow and atmospheric composition, J. Geophys. Res., in press, 1977.

Hudson, R. D., and L. I. Kieffer, Absorption cross sections of stratospheric molecules, CIAP monogr. 1, DOT-TST-75-71, Dep. of Transp., Washington, D. C., 1975 .

McDonnel1, J. C. and M. B. McElroy, Odd nitrogen in the atmosphere, J. Atmos. Sci., 30, 1465, 1973.

Meira, L. G., Jr., Rocket measurements of upper atmospheric nitric oxide and their consequences to the lower lonosphere, J. Geophys. Res., 76, 202, 1971.

Oran, E. S., P. S. Julienne, and D. F. Strobel, The aeronomy at odd nitrogen in the thermosphere, J. Geophys. Res., 80, 3068, 1975.

Pearce, J. B., Rocket measurement of nitric oxide between 60 and 96 kilometers, J. Geophys. Res., 74, 853, 1969.

Rusch, D. W., Satellite ultraviolet measurements of nitric oxide fluorescence with a diffusive transport mode1, J. Geophys. Res., 78, 5676, 1973.

Rusch, D. W., and C. A. Barth, Satellite measurements of nitric oxide in the polar region, $\mathrm{J}$. Geophys. Res., 80, 3719, 1975.

strobe1, D. F., Odd nitrogen in the mesosphere, J. Geophys. Res., 76, 8384, 1971.

strobel, D. F., Nitric oxide in the D region, J. Geophys. Res., 77, 1337, 1972.

Strobel, D. F., E. S. Oran, and P. D. Feldman, The aeronomy of odd nitrogen in the thermosphere, 2, Twilight emissions, J. Geophys. Res., 81, $3745,1976$. 
Tisone, G. C., Measurements of NO densities during sunrise at Kauai, J. Geophys. Res., 78, 746, 1973.

Tohmatsu, T., and N. Iwagami, Measurement of nitric oxide distribution in the upper atmosphere, Space Res., XV, 241, 1975.

Tohmatsu, T., and N. Iwagami, Measurement of nitric oxide abundance in equatorial upper atmo- sphere, J. Geomagn. Geoelec. Jap., 28, 343,

1976.

Tsang, T. H., Analysis of results of a rocketborne photometer for measurements of nitric oxide, M.S. thesis, Utah State Univ., Logan, 1975.

(Received February 4, 1977; accepted May 17, 1977). 